\title{
KONSEP EVALUASI PENDIDIKAN MENURUT IMAM AN-NAWAWI DALAM KITAB AL-MINHAJ SYARAH SHAHIH MUSLIM
}

\author{
Wardi Suwandi, Abas Mansur Tamam, Wido Supraha \\ Universitas Ibn Khaldun Bogor, Indonesia \\ Email: suwandi_wardi@yahoo.co.id
}

\begin{abstract}
ABSTRAK
Tujuan penelitian ini adalah untuk menganalisis konsep evaluasi pendidikan menurut Imam an-Nawawi dalam kitab al-Minhaj Syarah Shahih Muslim. Pendekatan yang dilakukan adalah studi riset kepustakaan (Library Riset) dengan bahasan pokok dari data primer maupun sekunder. Imam an-Nawawi mengemukakan secara langsung pendapat mazhabmazhab dan para ulama dan mengumpulkan pendapat yang paling kuat sesuai dengan hasil akhir ijtihadnya. Hasil penelitian menunjukkan bahwa konsep evaluasi pendidikan dapat dilihat dari keseluruhan dan klasifikasi materi hadits Imam Muslim pada kitab al-Minhaj yang menjadi pondasi evaluasi kurikulum pendidikan yang berlandaskan nilai-nilai iman, Islam, ihsan, ilmu dan adab. Konsep evaluasi harus di susun dan disesuaikan pada tiap tema dan kompetensi dasar dan dilaksanakan secara variatif dan berkelanjutan untuk menghimpun tercapainya tiga ranah penilaian yaitu afektif, kognitif dan psikomotor. (200 Kata)
\end{abstract}

Kata kunci: evaluasi; pendidikan; Imam an-Nawawi; al-Minhaj

\section{PENDAHULUAN}

Evaluasi termasuk pada salah satu sistem manajemen program pendidikan yang terdiri atas: Planning, Organizing, Motivating, Conforting (Pembinaan), Evaluating, dan Developing (Mengembangkan). (Mufah, 2017) Evaluasi juga merupakan salah satu komponen dalam pendidikan, Ramayulis menyebutkan enam komponen pendidkan yaitu: tujuan; pendidik; peserta didik; isi/materi; metode dan evaluasi. (Syarbini, 2014)

Evaluasi pendidikan adalah proses akhir dalam rangkaian proses pembelajaran. Evaluasi pendidikan yang dilakukan dengan cara yang pragmatis, akan menghasilkan lulusan yang pragmatis pula. Evaluasi pragmatis selalu mengukur dengan angka yang dihasilkan, tanpa melihat proses pendidikan yang panjang. Kelulusan hanya dinilai atas dasar angka ujian kognitif dari masing-masing siswa, bukan diarahkan pada uji kelulusan akhlak mereka. Pantas jika lulusan yang ada tidak berkualitas dan tidak bisa di pertanggungjawabkan secara moral. Dampak sosialnya adalah lulusan dari lembaga pendidikan, bukannya memberi solusi bagi problematika sosial, tetapi justru menambah beban sosial baru di masyarakat, karena lulusan yang ada, tidak sesuai dengan harapan dan tujuan pendidikan itu sendiri. (Alim, 2014) Evaluasi sebagai bagian dari sebuah kurikulum pendidikan memberikan kontribusi akhir yang baik dalam menghasilkan output pendidikan yang berkualitas yaitu cerdas dan beradab. Penulis 
mengampil pemiliran dan konsep Imam an-Nawawi yang secara langsung mengkomparasikan pendapat mazhab-mazhab dan para ulama dan mengumpulkan pendapat yang paling kuat sesuai dengan hasil akhir ijtihadnya yang diterangkan dalam kitabnya yang agung, yang tergolong sebagai induk kitab-kitab Islam, yaitu al-Minhaj. Kitab ini mendapat pujian dari para ulama terutama oleh al-Hafidz Ibn Katsir al-Dimisqi. (an-Nawawi, al-Adzkar, 2016; anNawawi, al-Minhaj Syarah Shahih Muslim, 2016)

\section{METODE PENELITIAN}

Jenis penelitian yang digunakan dalam mencari data adalah studi riset kepustakaan (library reseach) yaitu penelitian yang menggunakan cara untuk mendapatkan data informasi dengan memanfaatkan fasilitas yang ada diperpustakaan, seperti buku-buku, majalah, dokumen, catatan, kisah-kisah sejarah. (Arizqi Ihsan Pratama, 2019) Sedangkan metode analisis yang digunakan untuk mengungkap gagasan dan pemikirannya adalah metode analitik deskriptif. Konsep evaluasi pendidikan menurut Imam an-Nawawi dalam kitab al-Minhaj syarah Shahih Muslim ditelaah dan dikaji berupa data verbal yang dianalisis oleh penulis menjadi sebuah kesimpulan tentang konsep evaluasi pendidikan.

\section{PEMBAHASAN}

Para ulama telah bersepakat bahwasanya kitab yang paling shahih setelah Al-Qur'an adalah ash-Shahihain (dua kitab shahih), yaitu Shahih Bukhari dan Shahih Muslim. (anNawawi, al- Minhaj Syarah Shahih Muslim, 2017) Syaikh Imam Abu Amr bin Ash-Shalah Rahimahullah berkata, "Muslim Rahimahullah menetapkan persyaratan didalam karyanya (ash-Shahih), yaitu bahwa hadits itu harus mutassil al-isnaad (memiliki sanad yang bersambung) dengan penukilannya yang lebih tsiqah, dari awal sanad hingga akhirnya, terbebas dari keterasingan dan cacat.” (an-Nawawi, al-Minhaj Syarah Shahih Muslim, 2017)

Di antara ilmu yang paling penting adalah pengetahuan tentang Hadits-hadits Nabi, yang saya maksudkan adalah mengetahui matan-matannya, beserta hukum shahih, hasan, dha'if, muttasil, mursal, munqathi', mu'dal, maqlub, masyhur, gharib, aziz, mutawatir, ahad, serta para individu yang meriwayatkannya, tentang cacat-cacat Hadits, munkar, maudhu', mudraj, nasikh dan mansukh, khusus dan umum, mujmal dan mubayyan serta yang menyelisihinya, dan lain sebagainya. Tidak kalah penting juga mempelajari sanad-sanad, yakni mengetahui 
kondisi para perawi, sifat-sifat mereka, mengetahui secara detail nama-nama dan nasab mereka, kelahiran, kematian dan sifat-sifat lainnya. Kemudian mengetahui sifat tadlis dan para pelakunya, cara pengambilan pelajaran dan pengamatan mengenainya. Mengetahui keadaan para perawi tentang isnad, matan, maushul, mursal, mauquf, marfu', maqthu, munqathi', dan penambahan kepercayaan (tsiqah). (an-Nawawi, al-Minhaj Syarah Shahih Muslim, 2017)

Dua kitab shahih yakni shahih al-Bukhari dan shahih Muslim merupakan buah tangan dari Abu Abdillah Muhammad bin Ismail al-Bukhari dan Abu al-Husain Muslim bin al-Hajjaj al-Qusyairi ra., yang tidak didapati karya semisal dengan keduanya, sehingga diperlukan perhatian untuk menjabarkan keterangan-keterangan hadits tersebut, mengambil faedah-faedahnya, mengeluarkan secara detail ilmu-ilmu yang dikandung dalam matan dan isnad keduanya sebagaimana yang telah kami sebutkan sebelumnya berupa hujjah-hujjah yang nyata. (an-Nawawi, al- Minhaj Syarah Shahih Muslim, 2017)

Konsep evaluasi pendidikan menurut Imam an-Nawawi dapat dilihat dari keseluruhan dan klasifikasi materi hadits Imam Muslim pada kitab al-Minhaj yang berjumlah 7479 hadits. Evaluasi berdasarkan pemikiran Imam an-Nawawi pada kitab al-Minhaj Syarah Shahih Muslim tentang evaluasi pendidikan terhimpun kedalam lima bagian pokok, yaitu Iman, Islam, Ihsan, Adab dan Ilmu.

\section{Iman}

Pengertian iman telah dijelaskan oleh Rasulullâh saw. yaitu, "beriman kepada Allâh, para malaikat-Nya, kitab-Nya, perjumpaan dengan-Nya, rasul-rasul-Nya, dan kamu beriman kepada kepada hari kebangkitan akhir”. (an-Nawawi, al-Minhaj Syarah Shahih Muslim, 2017)

Materi tentang iman adalah hal pertama yang di tulis dan di susun pada kitab al-Minhaj. Imam an-Nawawi menjelaskan tentang definisi iman dengan mengambil pendapat Syaikh Abdurrazzaq ,"Aku mendengar orang yang telah aku jumpai dari kalangan syaikh-syaikh dan sahabat-sahabat kami, seperti Syufyan ats-Tsauri, Malik bin Anas, Ubaidilah bin Amr, alAuza'i, Ma'mar bin Rasyid, Ibn Juraij, dan Sufyan bin Uyainah berkata, "Iman adalah perkataan dan amal perbuatan, ia dapat bertambah dan berkurang dan hal tersebut sama dengan pendapat Ibnu Mas'ud, Hudzaifah, an-Nakha'i, al-Hasan al-Basri, Atha', Thawus, Mujahid dan Abdullah bin Mubarrak.” Jadi, perkara yang menjadikan seorang hamba berhak mendapat pujian dan perwalian dari kaum mukminin adalah dia melaksanakan ketiga perkara 
ini, yaitu mempercayai dengan hati, mengikrarkan dengan lisan, dan mengamalkan dengan anggota badan. Karena tidak ada perbedaan antara para ulama bahwa jika seorang berikrar dan beramal tanpa ilmu dan pengetahuan tentang $R a b b$, maka orang tersebut tidak berhak mendapatkan sebutan seorang mukmin. Jika dia mengetahui-Nya dan beramal, tetapi membangkang dengan hatinya dan mendustakan tauhid yang telah dia ketahui, maka dia tidak berhak mendapatkan sebutan nama mukmin. Demikian juga jika dia yakin kepada Allâh swt. dan seluruh Rasul-Nya, tetapi dia tidak mengamalkan kewajiban-kewajiban, maka dia tidak dinamakan sebagai mukmin secara mutlak. Meskipun menurut ungkapan orang-orang Arab, orang tersebut dinamakan sebagai mukmin lantaran kepercayaannya itu. (an-Nawawi, alMinhaj Syarah Shahih Muslim, 2017)

Iman yang ada pada hati manusia berasal dari merasakan keberadaan manusi dan alam semesta. Keberadaan beranekan ragam alam dan makhluk menjadi saksi atas keberadaan pencipta-Nya, yaitu Allah swt. Pasalnya, dialam semesta ini tidak ada yang mengklaim sebagai pencipta ataupun yang telah mewujudkan seluruh alam dan makhluk selain Allah semata. Akal manusia juga menilai mustahil adanya sesuatu tanpa ada yang menciptakannya. (al-Jazairi, 2015)

Pada pendidikan tingkat dasar hal yang sederhana dapat kita ajarkan kepada siswa adalah kita harus mengucapkan terima-kasih kepada seseorang yang telah memberikan sesuatu yang bermanfaat. Ucapan terima-kasih adalah bahasa yang sederhana tetapi dapat memisahkan seseorang apakah menjadi hamba yang bersyukur atau hamba yang kufur kepada Allâh. Bagaimana dengan Allâh yang maha memberikan rizki?. Menurut Supana, al-Maturidi berpendapat bahwa anak yang telah berakal berkewajiban mengetahui Tuhan. Kematangan akallah, menurutnya, yang menentukan kewajiban-kewajiban mengetahui Tuhan bagi anak, bukan tercapainya usia dewasa oleh anak. Ia juga beranggapan bahwa akal manusia dapat mengetahui kewajiban berterima kasih kepada Tuhan, karena Dia pemberi nikmat yang terbesar; dan dalam hidup sehari-hari akal dapat mengetahui keharusan berterima kasih kepada pemberi nikmat. (Supiana, 2004)

Evaluasi yang dilaksanakan pada setiap jenjang pendidikan terutama pada pendidikan dasar dan menengah bagi setiap muslim adalah dengan memulai nilai-nilai pembiasaan pada praktik ibadah peserta didik. Pertama ,menanamkan tauhid dan akidah yang lurus, megajarkan sifat wajib, sifat jaiz dan sifat mustahil bagi Allah dan Rasul. Ibadah yang ikhlas hanya umtuk 
Allah swt. Kedua, mengetahui nama-nama malaikat dan tugas-tugasnya sehingga membentuk pribadi yang cerdas dzahir dan bathin. Ketiga, mempelajari Al-qur'an dalam bacaan, menadaburi makna dan isi dan berusaha melaksanakan nilai-nilai Al-Qur'an. Keempat, mempelajari kisah nabi dan rasul Allah dan menjadikan pelajaran yang baik (ibrah hasanah) sehinng siswa menjadi pribadi yang terbimbing dengan suri tauladan yang nyata dan haqiqi kerena para nabi dan rasul kepada nilai kebenaran yang mutlaq. Kelima, mengimani hari akhir menjadikan siswa berusaha menjadi pribadi yang selalu bermanfaat baik bagi dirinya maupun orang lain karena seluruh amal perbuatan manusia akan dihisab oleh Allah swt. Keena, selalu menerima taqdir dan selalu bertawakal hanya kepada Allah swt.

Manusia yang bertauhid adalah manusia yang merasakan indera dan akalya merasakan keberadaan Allah. Dengan indera dan akalnya, manusia mampu mengamati dan mentafakuri kekuasaan Allah swt. baik di langit maupun di bumi. Menurut akal sehat, mustahil alam yang sangat mengagumkan, kompleks dan teratur itu ada, kecuali karena ia diciptakan oleh Dzat yang Maha Mengetahui dan Maha Bijaksana. (Tamam, 2017)

\section{Islam}

Imam an-Nawawi berkata, mengutip pendapat al-Imam Abu Muhammad al-Husain bin Mas'ud al-Baghawi asy-Syafi'i Rahimahullâh berkata tentang hadits Jibril kepada Nabi saw. tentang iman dan Islam, dan jawaban beliau kepadanya, dia berkata, "Nabi saw. menjadikan Islam sebagai sebutan terhadap amal perbuatan yang zhahir; sedangkan iman sebagai sebutan terhadap sesuatu yang tersembunyi berupa keyakinan. Bukan berarti amal perbuatan zhahir tidak termasuk bagian dari iman dan meyakini dengan hati tidak termasuk bagian dari Islam, tidak! Akan tetapi, hal tersebut menunjukkan tentang rincian dari iman dan Islam lalu disatukan atas nama agama. Oleh karena itu, beliau saw. bersabda, "itu adalah Jibril, Dia mendatangi kalian untuk mengajarkan kepada kalian tentang agama kalian." Kepercayaan dan amal perbuatan masuk kedalam sebutan iman dan Islam seluruhnya. Allâh swt. mengabarkan bahwa agama yang telah Dia ridhai bagi hamba-hamba-Nya dan agama yang diterima oleh-Nya adalah agama Islam. Agama itu tidak mungkin akan diterima dan diridhai, melainkan dengan menyatukan antara keyakinan dan amal perbuatan. (an-Nawawi, al- Minhaj Syarah Shahih Muslim, 2017) Imam an-Nawawi mengutip pendapat Syaikh Abu Amr bin ashShalah Rahimahullah berkata, Sabda Beliau saw.,: 
Islam adalah kamu bersaksi bahwa tidak ada tuhan (yang berhak disembah) kecuali Allah dan bahwa Muhammad adalah utusan Allah; kamu mendirikan shalat; kamu menunaikan zakat; kamu berpuasa Ramadhan; dan kamu berhaji jika mampu melaksanakannya...dan iman adalah kamu beriman kepada Allah; malaikat-malaikat-Nya; kitab-kitab-Nya; rasul-rasul-Nya; dan hari akhir; dan kamu beriman kepada takdir yang baik dan yang buruk".

Imam an-Nawawi mengutip pendapat asy-Syaikh Abu Amr bin ash-Shalah tentang iman dan Islam, sebutan Islam juga mencakup pokok keimanan, yaitu keyakinan batin; serta mencakup pokok-pokok ketaatan. Karena sesungguhnya itu semua adalah bentuk keberserahan diri. Berdasarkan apa yang telah kami sebutkan dan kami tahkik menghasilkan bahwa iman dan Islam dapat berkumpul dan berpisah; dan sesungguhnya setiap mukmin adalah muslim, tetapi tidak setiap muslim adalah mukmin. (an-Nawawi, al-Minhaj Syarah Shahih Muslim, 2017)

\section{Ihsan}

Ketika Rasulullah saw. ditanya oleh seorang laki-laki ditengah para sahabat, "Wahai Rasulullah, apa itu ihsan?" Sabda Nabi saw. "Kamu takut kepada Allah swt. seakan-akan kamu melihat-Nya. Sesungguhnya, jika kamu tidak melihat-Nya, maka sesungguhnya Dia melihatmu.” (an-Nawawi, al-Minhaj Syarah Shahih Muslim, 2017)

Sabda Nabi saw. "Ihsan adalah kaтu menyenbah Allah seakan-akan kaтu melihat-Nya. Meskipun kamu tidak melihat-Nya, maka sesungguhnya Dia melihatmu". Sifat ihsan tersebut merupakan anugerah yang diberikan Allâh kepada beliau. Sebab, seseorang yang berhadapan dengan Rabb-nya untuk melaksanakan suatu ibadah, maka dia tidak akan berpaling, tetapi tunduk penuh dengan kekhusyu'an. Melakukannya dengan sebaik-baiknya, baik zhahir maupun batin, dan dia pasti akan berusaha untuk melakukannya dengan sempurna. Sehingga Beliau saw. bersabda, "Beribadahlah kamu kepada Allâh didalam semua kondisimu, seperti kamu beribadah pada saat berhadapan mata." Tujuan tersebut dapat diwujudkan meskipun seorang hamba tidak melihat Allâh, sehingga sudah sepantasnya bagi dia untuk beramal dengan ketentuan ihsan. (an-Nawawi, al-Minhaj Syarah Shahih Muslim, 2017)

Sifat ihsan membuat manuasia selalu mengevaluasi diri. Evaluasi diri adalah menjaga fitrah manusia agar tetap menjadi hamba Allâh 粠 yang beriman dan berakhlak mulia, maka wajib bagi seorang muslim selalu mengevaluasi dirinya dan selalu memperbaikinya. Secara 
garis besar dikenal dua jenis akhlak; yaitu akhlak al-mahmudah (akhlak terpuji), akhlak yang baik dan benar menurut syariat Islam, dan akhlak al-mazmumah (akhlak tercela), akhlak yang tidak baik dan tidak benar menurut syariat Islam. (Syafri, 2014)

\section{Adab}

Imam an-Nawawi menjelaskan proses memuliakan manusia sebagaimana tuntunan ayatayat Al-Qur'an dan Hadits-hadits Rasulullâh saw. sehingga menjadi keshalihan adalah sebuah proses panjang. Adab adalah kesopanan, kehalusan dan kebaikan budi pekerti. (KBBI, 1989)

Dalam bahasa arab, kata adab merupakan bentuk kata dari kata kerja adaba yang berarti kesopanan, sopan santun, tata karma, moral, nilai-nilai yang dianggap baik oleh masyarakat.

Adab didalam kitab al-Minhaj dijelaskan secara lengkap dan terperinci yang merupakan penjelasan dari Hadits-hadits shahih Rasulullâh saw. dari Imam Muslim, diantaranya, yaitu:

a. Adab wajib berbakti kepada orang tua.

Rasulullâh saw. bersabda : Dari Abu Hurairah radhiyallahu 'anhu dia berkata; "Seorang laki-laki datang kepada Rasulullah saw. sambil berkata; "Wahai Rasulullah, siapakah orang yang paling berhak aku berbakti kepadanya?” Beliau menjawab: "Ibumu.”Dia bertanya lagi;"Kemudian siapa?” Beliau menjawab: “Ibumu.”Dia bertanya lagi; “Kemudian siapa lagi?” Beliau menjawab: “Ibumu.” Dia bertanya lagi; "Kemudian siapa?" Beliau menjawab: "Kemudian ayahmu." (HR. Muslim, Kitab Al-Minhaj Hadits ke-6447).

b. Adab berbakti mengutamakan kedua orang tua daripada shalat sunnah dan perkara sunnah lainnya (Kitab Al-Minhaj Hadits ke-6455).

c. Adab bersilaturrahim kepada teman-teman ayah dan ibu (Kitab Al-Minhaj Hadits ke6460).

d. Adab menyambung tali silaturrahim.

Bersabda Rasulullah saw. : "Barangsiapa yang suka diluaskan rizkinya dan ditangguhkan ajalnya, hendaklah ia bertaqwa kepada Allah dan menyambung silaturahim”. (HR. Muslim, Kitab al-Minhaj Hadits ke-6470).

Imam an-Nawawi berkata, hakikat makna shilah ( menyambung) adalah mengasihi dan menyayangi. Beliau mengutip pendapat Al-Qadhi Iyadh berkata, Rahim yang dimaksudkan disini yang mana ia bisa disambung, diputuskan, dan diperlakukan dengan baik adalah arti maknawi (abstrak), bukan Rahim yang berbentuk fisik (konkret), yaitu hubungan kekerabatan 
dan nasab (garis keturunan) yang disatukan oleh rahim seorang wanita, sehingga antara satu dan yang lainnya berhubungan. (an-Nawawi, al- Minhaj Syarah Shahih Muslim, 2017) Maka, sambungannya itu disebut rahim (Silaturrahim) yang artinya hubungan kekerabatan untuk saling mendo'akan, membantu, tolong menolong dengan kasih sayang dan dalam kebaikan.

Adapun adab terhadap Al-Qur'an Imam an-Nawawi secara khusus menulis kitab atTibyan fii Adabi Hamalatil Qur'an yang membahas adab-adab terhadap Al-Qur'an, yaitu mengenai: Keutamaan pembaca dan penghapal Al-Qur'an; keutamaan Qiraah dan ahli Qiraah; keharusan memuliakan ahlul-Qur'an dan larangan menyakiti mereka; adab pengajar dan pelajar Al-Qur'an; adab para penghapal Al-Qur'an;adab membaca Al-Qur'an; dan adab terhadap Al-Qur'an. Imam an-Nawawi menuturkan, diantara penghormatan terhadap AlQur'an, yaitu menghindari tertawa, bersorak-sorai, dan berbincang-bincang. (an-Nawawi, atTibyan fii adabi Hamalatil qur'an, 2018)

\section{Ilmu}

Dalam bahasa arab al-ilm berarti pengetahuan (knowledge), sedangkan kata "ilmu" dalam bahasa Indonesia biasanya merupakan terjemahan science. Ilmu dalam arti science itu hanya sebagian dari al- 'ilm dalam bahasa Arab. (Tafsir, 2014)

Kata science yang ditemukan dalam literature, umumnya diterjemahkan menjadi "sains", dan knowledge menjadi "ilmu", atau "pengetahuan" atau "pengenalan" yang disesuaikan dengan konteksnya. Hal ini untuk menghindari asumsi-asumsi para penganjur sains dan filsafat modern bahwa sains merupakan satu-satunya ilmu yang otentik; bahwa ilmu hanya bersangkut-paut dengan fenomena; bahwa sains, termasuk pernyataan-pernyataan dasar dan kesimpulan-kesimpukan umum sains dan filsafat yang diturunkan darinya, adalah khas bagi zaman tertentu, dan dapat berubah dalam zaman yang lain, sebagaimana yang dijelaskan oleh Syed Muhammad Naquib al-Attas dalam Islam dan Filsafat Sains. (Supraha, 2018)

Menuntut ilmu merupakan kewajiban bagi setiap muslim, merupakan bentuk rasa syukur atas kesempurnaan manusia secara zahir dan bathin. Dengan ilmu manusia dapat beribadah kepada Al-Khalik dengan beramal shalih yang menuju kebahagiaan yang hakiki. Imam anNawawi mengungkapkan jalan menjadi orang-orang yang shalih dengan kata-kata beliau dalam pengantar kitab Riyadhus Shalihin : Maka oleh karena itu saya ingin menghimpun sebuah ringkasan dari hadits-hadits shahih, yang mencakup semua yang seharusnya menjadi jalan titian menuju akhirat bagi pemiliknya, memenuhi adab-adabnya yang bathin maupun 
yang zahir, merangkum targhib, tarhib dan berbagai macam adab orang yang menempuh jalan Islam, hadits-hadits zuhud, latihan-latihan jiwa, pembersihan akhlak, kesucian-kesucian hati dan obat-obatnya, memelihara anggota badan dan menghilangkan penyimpangannya dan lain sebagainya dari berbagai macam maksud orang-orang arif. (an-Nawawi, Riyadhus Shalihin, 2005)

Kitab al-minhaj syarah shahih Muslim menjelaskan tentang ilmu yang menjadi pokok yang harus dipelajari dan dikuasi oleh umat Islam. Jika di himpun dengan suatu pemetaan maka didalam kitab al-Minhaj terhimpun rangkaian ilmu tafsir Al-Qur'an, akidah, syaria'ah dan adab yang menjadi pondasi utama dalam evaluasi pendidikan bagi seorang muslim. Bab larangan mengikuti ayat-ayat mutasyabihat dan larangan berbantahan tentang Al-Qur'an (Hadits 6717, 6718, 6719, 6720). Bab hilang dan diangkatnya ilmu (agama Islam) dan timbulnya kebodohan dan bencana di akhir zaman (Hadits nomor 6726-6740). Rasulullâh saw. bersabda : Sesungguhnya Allah tidak mengambil ilmu dengan cara mencabut (nyawa) para ulama, sehingga ketika Allah tidak meninggalkan seorang ulama pun, manusia akan mengangkat pemimpin-pemimpin yang bodoh dan apabila ditanya mereka akan memberikan fatwa tanpa didasarkan ilmu lalu mereka pun sesat serta menyesatkan.” (HR. Muslim nomor 6740 kitab al-Minhaj).

Hadits ini menjelaskan bagaimana Allâh swt. menghapus ilmu agama dari muka bumi; ternyata bukan dengan menghapuskannya dari pikiran dan hati-hati para pemiliknya, tetapi dengan cara mencabut nyawa mereka, sehingga ilmunya juga ikut terkubur. Kemudian umat manusia menjadikan orang-orang bodoh sebagai hakim pemutus masalah, sehingga mereka menjadi sesat dan menyesatkan. (an-Nawawi, Riyadhus Shalihin, 2005)

\section{KESIMPULAN}

Pokok dan dasar materi evaluasi menurut Imam an-Nawawi dalam kitab al-Minhaj Syarah Shahih Muslim yaitu Islam, Iman, Ihsan, Ilmu dan Adab. Lima konsep tersebut akan membetuk sistem evaluasi yang sempurna, karena nilai-nilai kebaikan dari hasil evaluasi yang diharapkan bukan hanya angka (system numeric) dan kelengkapan administrasi pembelajaran, tetapi berasal dari keteguhan dan istiqamahnya seseorang dalam berkeyakinan. Inilah yang menjadi pegangan awal seorang guru pendidikan agama Islam, untuk melakukan evaluasi pada mata pelajaran pendidikan agama Islam dalam menghasilkan lulusan (output) lembaga yang 
berkualitas. Keimanan dan keislaman peserta didik yang kaffah menghasilkan manusia yang cerdas pada setiap disiplin ilmu yang tentu mendatangkan kemaslahatan yang dilandasi tauhid kepada Allah swt. sehingga menjadi insan beradab dalam setiap gerak kehidupannya.

\section{DAFTAR PUSTAKA}

Alim, Akhmad. (2014). Tafsir Pendidikan Islam, Jakarta: AMP Press.

Arizki Ihsan Pratama, Musthaofa Zahir. (2019). Konsep Kepribadian Guru menurut Ibnu Sahnun. Tawazun: Jurnal Pendidikan Islam, 12.

Jabir al-Jazairi, Abu Bakar. (2015). Minhajul Muslim. Jakarta: Pustaka al-Kautsar.

Mufah, Jejen. (2017). Manajemen Pendidikan, Teori Kebijakan dan Praktik. Jakarta: Kencana. An-Nawawi, Imam. (2016). Al-Adzkar. Solo: Kuttab Publishing.

An-Nawawi, Imam. (2017) al-Minhaj Syarah Shahih Muslim. Jakarta: Darus Sunah.

An-Nawawi, Imam. (2005) Riyadhus Shalihin. Surabaya: Duta Ilmu.

An-Nawawi, Imam. (2018) at-Tibyan fii adabi Hamalatil Qur'an. Sukoharjo: Maktabah Ibnu Abbas.

Supiana dan Karman. (2004). Materi Pendidikan Agama Islam. Bandung: Rosdakarya.

Supraha,Wido. (2018). Pemikiran George Sarton dan Panduan Islamisasi Sains. Depok: Yayasan Adab Insan Mulia.

Syafri, Ulil Amri. (2014). Pendidikan Karakter Berbasis Al-Qur'an. Jakarta: Raja Grafindo Persada

Syarbini, Amirullah. (2014). Model Pendidikan Karakter dalam Keluarga. Jakarta: Elex Media Komputindo

Tafsir, Ahmad. (2014). Filsafat Ilmu. Bandung: Remaja Rosdakarya.

Tamam, Abas Mansur. (2017). Islamic Worldview Paradigma Intelektual Muslim. Jakarta: Spirit Media Press. 